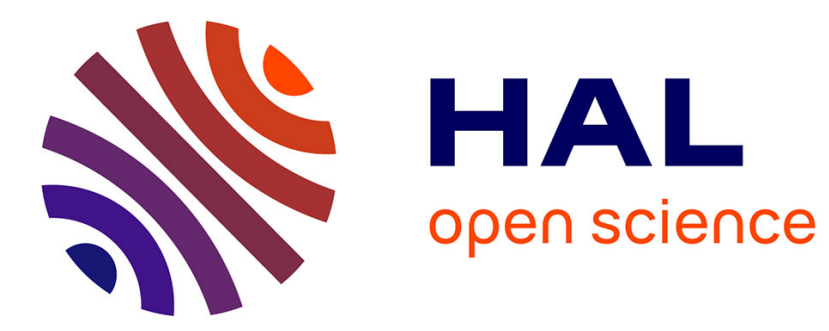

\title{
Smart city projects in the continuity of the urban socio-technical regime: The French case
}

Gilles Jeannot

\section{To cite this version:}

Gilles Jeannot. Smart city projects in the continuity of the urban socio-technical regime: The French case. Information Polity, 2019, 24 (3), pp.325-343. 10.3233/IP-190128 . hal-02309802

\section{HAL Id: hal-02309802 \\ https://hal-enpc.archives-ouvertes.fr/hal-02309802}

Submitted on 30 Oct 2019

HAL is a multi-disciplinary open access archive for the deposit and dissemination of scientific research documents, whether they are published or not. The documents may come from teaching and research institutions in France or abroad, or from public or private research centers.
L'archive ouverte pluridisciplinaire HAL, est destinée au dépôt et à la diffusion de documents scientifiques de niveau recherche, publiés ou non, émanant des établissements d'enseignement et de recherche français ou étrangers, des laboratoires publics ou privés. 


\title{
Smart city projects in the continuity of the urban socio-technical regime: The French case
}

\author{
Gilles Jeannot \\ LATTS, Ecole des ponts, 6 avenue Blaise Pascal, F 77455 Marne la vallée, Cedex 2, France \\ Tel.: +331816685 17; E-mail: jeannot@enpc.fr
}

\begin{abstract}
The purpose of the article is to assess whether smart city projects developed in France represent continuity or a break with the established socio-technical regime of French cities. Our assessment attempts to establish a link between the main socio-technical features of French cities in existing literature and an exhaustive list of "smart city"-labelled projects compiled from twenty French cities. It reveals more of continuity than a break with the urban socio-technical regime generated by these projects. Technologies are not evenly developed along different domains: the fact that the most sophisticated innovations play out in the regulation of networks rather than in e-government reinforces an old two-speed urban modernisation. The mainly technological character of these projects is part of the continuity of a depoliticised strategy for managing technical matters. Co-production opportunities renew a tradition of local management and processing of grievances. Traditional public-private partnerships are only partially modified.
\end{abstract}

Keywords: Smart city, e-government, smartphone, platforms, internet of things, big data, open data, France

\section{Key points for practitioners:}

Smart cities often emerge as a collection of technology-driven experimentations. Rather than an integrated model, the dominant development paradigm is an accumulation of sector-based innovations. In this context the article raises two points.

- The success of a particular experimentation depends on its capacity to get along with national organisational and political institutions. Smart city projects seem to be more popular when they strengthen longstanding features of the urban socio-technical regime. The modality of representative and participative democracy and the traditions of public private partnerships, in particular, could facilitate or hinder certain innovations.

- Technologies are not evenly developed in different domains. The innovations linked to sensors and data analytics are deployed in the regulation of networks. The link with citizens is more impacted by the combination of smartphone and GPS. The question of the integration of e-government is renewed by a possible technological gap or a two-speed modernization linked to this uneven development of technologies.

\section{Introduction}

The interest in smart cities is linked to a presumption of novelty. The first and most visible publications were produced by researchers directly associated with these practices and involved in promoting them (Angelidou, 2014; Batty, 2013; Jin et al., 2014; Schaffers et al., 2011). Interestingly, the geographers who followed were more critical of the consequences of smart cities than of the very presumption of novelty (Greenfield, 2013; Hollands, 2008, 2015). Here we question this presumption of novelty from a sociotechnical perspective by posing the opposite question of continuity and by developing an exploratory

$1570-1255 / 19 / \$ 35.00$ (c) 2019 - IOS Press and the authors. All rights reserved

This article is published online with Open Access and distributed under the terms of the Creative Commons Attribution NonCommercial License (CC BY-NC 4.0). 
approach based on the analysis of an exhaustive list of smart city projects throughout France as a country case study.

We ask to what extent these new developments represent continuity or a break with the past. As Meijer and Thaens (2018b) noted, "Contextual studies of smart cities result in interesting findings but tend to ignore (1) the fact that smart city technologies build upon existing physical infrastructures and (2) that networks of actors working on smart cities often build upon earlier collaborations". Analysing these issues of continuity versus break with the past is also a way of tackling questions about city governance, changing relations between stakeholders and different forms of partnership.

The originality of the exploratory approach proposed here is its positioning at the scale of a country to replace urban technological innovations (Meijer \& Thaens, 2018) associated with the discourse on smart cities from the perspective of continuity of the socio-technical regime. This scale is indeed quite important since a large part of institutional frameworks are defined at the national level. In keeping with the global approach we have chosen, we will not define the key relevant questions but start with a review of the existing research on the socio-technical dimensions of French cities to define the relevant criteria for analysing these smart city projects. These criteria include the differentiation of practices according to functions, the challenges of democracy and the development of public/private partnerships. The originality also lies in the data collection method inspired by work on management tools in municipal administrations (Kuhlmann et al., 2008; Poister \& Streib, 1994). It is based not on case studies but on the analysis of the range of innovations deployed in an (undifferentiated) set of twenty French cities. France makes for an interesting case study because relatively little research has been carried out on smart cities and because the French model appears singular with a longstanding communal system rooted in old parishes and the importance accorded to a specific form of public-private partnership exported throughout the world (Lorrain, 2005).

The few empirical studies conducted in France on smart cities have firstly documented the question of new public-private sharing arrangements: certain services provided by major digital operators in experimental districts (various services focused on controlling energy consumption provided by Toshiba in Lyon Confluence (Faivre d'Arcier et al., 2016), innovations supported by Cisco in Issy les Moulineaux and IBM in Nice (Veltz et al., 2018)), or the repositioning of traditional service groups also outlined in the field of transport (Huré, 2017) and green cities (Lorrain et al., 2018)). The development of digital technology could therefore provide an opportunity for a new privatisation of cities (Baraud Serfati, 2011) or the deployment of a new urban capitalism (Huré, 2017). In addition, specific attention has also been paid to forms of co-production with citizens using digital technology. Measures enabling residents to report and geo-locate problems on roads or with street equipments have been the subject of a cross-cutting analysis (De Feraudi \& Saujot, 2017). Participatory democracy has also been addressed through electronic voting (Zaza, 2016) and open data (Courmont, 2015; Denis \& Goëta, 2017). These works have therefore generally focused more on new relationships with private companies and citizens, although some resistance from government administrations (Courmont, 2015) or dominant urban service companies (Huré, 2017) has also been reported.

The purpose of the article is to present a general overview of smart city projects in France and to assess whether these projects represent a continuation or a break with the socio-technical regime of French cities. After the introduction 1), 2) we will justify the meaning of the notion of "continuity" in the globalizing perspective of the "socio-technical regime" (Geels, 2004; Rip \& Kemp, 1998). 3) We then propose a bibliographical review of works focusing on the socio-technical characteristics of French cities in order to analyse the evolution of the socio-technical regime. 4) The methodology is then presented. 5) Next, we present "smart city"-labelled projects in twenty French cities and we compile a list of specific 
projects deployed in these cities. "Smart city"-labelled applications are extremely varied and this makes it more complicated to present examples. By drawing upon one of the first exercises in systematically describing such projects (Neirotti et al., 2014), we will present projects by grouping them by "domain" (administration, services, regulation of urban networks, public policies, democracy). 6) We then go on to highlight several trends that emerge from a review of the literature on these smart city projects by theme: domain/technology ratio, democracy and public private sharing arrangements. 7) Finally, we link the characteristics of the socio-technical regime of French cities and the main trends highlighted by the smart city projects to discuss the issue of continuity and break with the past. 8) We ultimately find in favour of continuity, or rather a reinvention of the stabilised features of the socio-technical regime.

\section{Socio technical regimes and smart cities}

This whole question of continuity/break with the past is part of a socio-technical perspective of historical institutionalism. Analysing material and technological aspects results in markedly different perspectives depending on the level on which this materiality is perceived. The idea of path dependency linked to technological lock-in (see the example of the QWERTY keyboard (David, 1985) or nuclear reactors (Cowan, 1990)) may be applied to some localised innovations. Hughes (1993) developed the idea of momentum to complex organisational arrangements and technologies associated with an electrical network, a large technical system (Coutard, 2002). Paul Edwards renewed the debate over knowledge infrastructures such as the Internet (Edwards et al., 2009). This reflection was applied at city level by focusing on infrastructures (Dupuy \& Tarr, 1988; Graham \& Marvin 2002; Konvitz et al., 1990) or features of construction and urbanism (Aibar \& Bijker, 1997; Hommels, 2005). By harnessing actor network theory, Farias and Widmer (2018) advance the notion of socio-technical urban assemblages in a similar vein to Bruno Latour's intuitions concerning Paris (Latour \& Hermant, 2006).

However, this localised approach does not pinpoint the historical and institutional conditions that link the different cities within a country, which is the subject of this article. To tackle a larger part of an economic sector together with all of its stakeholders (i.e., public authorities, academics, businesses and users) Rip and Kemp (1998, p. 238) put forward the idea of a technological regime: "A technological regime is the rule-set or grammar embedded in a complex of engineering practices, production process technologies, product characteristics, skills and procedures, ways of handling relevant artefacts and persons, ways of defining problems - all of them embedded in institutions and infrastructures." To tackle the question of transition more specifically, Geels (2004) advances the concept of socio-technical regime, which incorporates dimensions of science and technology together with policy, culture and marketmaking, alongside technical practices. Here, we are referring to an "urban socio-technical regime" by applying the notion of socio-technical regime to an object that is narrower than the development of an economic sector.

The notion of regime generally evokes the stability in the workings of a machine or a social complex. This notion was applied by Rip and Kemp (1998) to socio-technical aspects to assess how to get around a society's difficulty in adapting technologically to major changes like climate change. It led them to observe that in protected "niche" conditions, certain innovations could flourish prior to being disseminated. Public measures to provide support for smart city experiments are implicitly based on this representation of innovation. Frank Geels (2004) takes up this argument to focus on sector-based innovation systems. First he talks about integrating numerous components: businesses from the same technological sector, users and governments which regulate the process. Following in the footsteps of Hughes (1993), he also stresses the weight of specifically material dimensions. He then focuses on three factors of this stability: 
regulatory elements (laws), normative elements (values) and cognitive elements (symbols, paradigms). This dual extension, both to objects of attention and forms of regulation is summarised by Senger et al. (2016): "networks of actors and social groups, formal, normative and cognitive rules, material and technical elements". The socio-technical regime itself straddles other regimes: technology, science, policy, socio-culture and markets. This conceptualisation makes it possible to move from factors of continuity associated with other actors at the level of local experimentation to the transformation of society on a larger scale, particularly that of a country, the level at which the bulk of the legislative framework and the fundamental values of the population and certain ways of thinking are defined.

After being neglected (Meijer \& Bolivar, 2013), the first applications of the socio-technical approach began to be developed with regard to smart cities (Meijer \& Thaens, 2018b). They were applied to specific objects: the "living lab" (Baccarne et al., 2014; Meijer \& Thaens, 2016), smart grids (Bulkeley et al., 2016), planning practices (Luque Ayala \& Marvin, 2015), dashboards for urban monitoring (Kitchin, 2014). This focus on technical materiality made it possible to analyse "publicness" (Cowley et al., 2018), the place of infrastructure (Veltz et al., 2018), a new general experimentation paradigm (Evans et al., 2016) or cities' capacity to reinvent projects (Karvonen et al., 2018).

If we stay within the specific theoretical framework of the socio-technical regime, a number of applications to smart cities appear. The socio-technical regime approach has been mostly used in relation to the energy transition (Markard et al., 2012) and green cities, however a working group concerned with the work of Geels (Koehler et al., 2017) has put the issue of smart cities on its agenda. The overall Geels innovation system approach that we have chosen has been applied centrally to the theme of smart cities to study completely new neighbourhood or city projects ("smart city from scratch") (Carvahlo, 2014) or sets of experiments in classic cities Austin (McLean et al., 2016), Amsterdam (van Winden \& van de Buuse, 2017), Turin (Turletti, 2014), or to compare different national contexts across three cities (Amsterdam, Hamburg and Nigbo) (Raven et al., 2019). With a few exceptions (Henriot et al., 2018), an approach inspired by Geels and applied at a national level has not really been developed yet.

\section{The urban socio-technical regime of French cities}

\subsection{The socio-political features of French cities}

French communes (or municipalities) emerged after the French Revolution and reflected the wish to create an autonomous level of management in the old parishes. Although the institutional landscape subsequently underwent a huge transformation, particularly with the merging of a number of communes into intercommunalités, and the creation of "métropoles" in the big cities, the long-term results include scale-related effects and local democracy and related activities.

The communes mainly provide day-to-day services determined by the legislative sharing of expertise between different administrative levels. The various phases of decentralisation engaged since 1983 have entrusted the communes with responsibilities and expertise in the domains of urbanism, social housing, transport, the environment (water, waste management) and culture. Education is a national government prerogative but the communes are in charge of the upkeep of primary school buildings and this currently includes providing computers in the classroom. Municipal managers are very much focused on economic development issues although their means of action remain indirect (i.e., communication, coordination, planning, infrastructure, etc.). Under the Constitution, the communes have full administrative powers in these areas. 
A great many tasks are still provided by public employees and three-quarters of municipal agents are recruited at a low level and sometimes even as part of employment support-type social policies (Biland, 2010). Certain tasks, such as the upkeep of public spaces and parks or reception facilities at the town hall, or governmental missions (identity cards) may remain relatively "un-modernized" from a management and technological perspective (Lorrain, 1991).

A specific form of public-private partnership, the concession arrangement, has developed since the nineteenth century (Bezançon, 1997), making it possible to farm out the various different networks (water, sewage, public transport, etc.) to private companies or to manage them under municipal concession arrangements. The concession operators enter into long-term relationships built on trust. The position of the operators was subsequently strengthened by their international development (Lorrain, 2005). This involves French cities in a particular form of urban capitalism that differs for example from the German model built around large local public enterprises present in multiple sectors (Stadtwerke) (Barraqué, 1992), or the UK model generally based around organising tenders between private companies (Lorrain, 2005b).

The commune is a place of active democracy: the local council (conseil municipal) is elected by popular vote and in turn elects the mayor. While the mayor represents the commune in a strong and symbolic manner, his/her election may depend on coalitions made up of different parties. In this case, certain areas are entrusted to elected deputy mayors who have their own legitimacy (Borraz, 1995). Mayors often complete several terms, backed by shifting coalitions, and their longevity feeds on the image of their ambition to develop the city and the quality of service for users. The more ideological issues that structure national public debates are also euphemised. The fact that the heads of urban councils (agglomérations) are not elected by popular vote reinforces this shift towards depoliticization in the largest cities (Desage \& Gueranger, 2011).

There is a strong correlation between the quality of services and getting elected. Partisanship is often circumvented by opinions concerning day-to-day management and French people have a more favourable opinion of their local councillors than of their national elected representatives. Over the past few years, certain councils have focused on bringing municipal structures into line with participative democracy, either by hooking neighbourhood committees up to decentralised municipal services or by transferring a significant chunk of the budget for renovating public spaces into participatory budget-type arrangements (Nez, 2011).

The French system was long criticised for the huge number of communes but this is no longer the case after a series of laws passed since 1999 to progressively integrate them. The communes remain but they are now integrated into public inter-municipal establishments within an overlapping system of tasksharing. 36,000 communes have been supplanted by 1,266 inter-municipal establishments (établissements intercommunaux) that cover the entire country. This partially integrated structure is now referred to as a "communal block". Nevertheless, the legislator did not want to remove the democratic legitimacy of the communes and the most symbolic missions involving contact with the population have been left at this level.

\subsection{The urban socio-technical regime of French cities}

These key features of a "communal block" have less directly visible effects on the block's technical operation. We can draw upon old and converging research to draw up a picture of this socio-technical regime.

This wish to break free from ideology highlights the supposedly neutral character of the technique. 
This may have been the case with urbanism over the long term (Dupuy, 1978) or with the supply of network infrastructure. Concerning administration management and regulation of the networks, "invisible pilots" (Lorrain, 2004) dispense with the need to reopen ideological debates.

French communes have leveraged day-to-day expertise and a willingness to legitimise everyday action to build services around the idea of proximity and responsiveness. Processing letters of complaint and the reaction to information fed back to local council elected representatives or employees have always been used to flag up the problems perceived by the population, particularly those related to the upkeep of public spaces (Barthelemy, 1989; Jeannot, 1995). A number of big cities have also set up neighbourhood-based services to provide a more suitably-adapted response. Participative democracy whose vitality varies considerably from one French city to another - has largely appeared in the wake of these developments. In cities like Paris, participative budgets sometimes account for the bulk of amounts set aside for micro-managing public spaces.

Modern technological and management processes are appearing in cities at a varying pace. Certain administrative and governmental tasks such as the upkeep of public spaces are still carried out in a traditional manner using unskilled personnel. However, we note the use of more sophisticated practices in the management of urban networks or the construction and management of certain facilities. This differentiation was already apparent in the computerisation of French cities in 1990: certain smart cityrelated practices concerning automatic regulation of networks were already in gestation even though modernisation of the administrative management apparatus appeared to lag far behind (Dupuy, 1992).

\subsection{Relevant characteristics for the analysis of smart city projects in France}

The review of socio-technical research into French municipal administrations makes it possible to identify the relevant questions for the survey on smart city projects. First of all, it appears that the different tasks carried by cities provide a basis for differentiating socio-technical developments, leading us to analyse successively different domains and to develop an analysis of the uneven dissemination of technologies along various domains. Secondly, the issues related to democracy appear to be directly relevant to the evolution of the socio-technical system. Finally, the sharing of roles between the public and private sectors and the significance of the development of public-private partnerships are also important in the debate.

\section{Methodology}

In order to avoid pitting futuristic predictions (Anthopoulos, 2017) or general principles concerning the smart city against the empirical realities of e-governance, we need to start with concrete initiatives already undertaken as part of any research into "actually existing smart cities" (Shelton et al., 2015) or "ordinary smart cities" (Farias \& Widmer, 2018). Because the measurement of new practices is also in its infancy, we will use an original method of identifying socio-technical processes associated with smart cities which we will apply to 20 French cities.

Our proposed approach adheres to the practice of focusing on management applications or administrative process innovations (Meeus \& Edquist, 2006) initiated in the US (Poister \& Streib, 1994) that has sometimes been used in Europe (Jeannot \& Guillemot, 2010; Jeannot et al., 2018; Kuhlman et al., 2008). In such surveys, the general theme of changing administration management practices is tackled by segmenting practices into management tools, i.e., simple, easily quantifiable units. Obviously, we 
sacrifice a little of the complexity of each situation but because this allows for a certain degree of decontextualisation, comparisons may be made. This research approach is used here in an exploratory phase in order to identify the socio-technical processes currently used in cities.

Although it is declarative, we are aiming to identify practices actually deployed in French cities. But for the moment, we are not trying to measure the development of such socio-technical processes or even produce an original typology, but, more modestly, to use the list of effective innovations associated with the smart city to highlight a few salient characteristics to compare to socio technical regime characteristics of the local government in France.

First off, we have drawn up an ensemble of French cities that have been promoted as "smart cities" based on a number of different sources, i.e., EU funding, public investment bank funding and several awards sponsored by businesses or newspapers. We have taken the ten biggest French cities (population in brackets) (Paris (2200000), Marseille (860000), Lyon (515000), Toulouse (475000), Nice (343000), Nantes (307000), Montpelier (282000), Strasbourg (279000), Bordeaux (252000), Lille (232000)) and ten among those most frequently cited from among the smaller-sized cities (i.e., Rennes (216000), Grenoble (158000), Dijon (155000), Besançon (116000), Mulhouse (108000), Rouen (110000), SaintDenis (110000), Issy les Moulineaux (70000), Chartres (39000)). Without being exhaustive, this choice of cities makes it possible to cover most of the innovations developed in France by covering contexts associated with different sized cities. The method does not aim to compare the practices of different cities, or to discuss whether or not these cities deserve to be characterized as "smart cities", but to establish the broadest possible list of smart city projects developed in French cities.

Working from this ensemble, we then conducted systematic searches on their websites and other communication media for bottom-up labelling (Anthopoulos, 2017) and in projects funded and in the specialised press for top-down labelling. This gave us a list of "smart city"-labelled socio-technical processes that was either stabilised or in the experimental phase. This undifferentiated list represents the material of our survey (which will be summarized in Table 1).

We classified these projects based around different municipal government domains (Neirotti et al., 2014) - i.e., administration, services, urban network regulation, public policies and democracy - even though original practices such as "open data" or cross-checking miscellaneous data (traditional or "big data") tend to shake up this classification.

\section{5. 'Smart city'-labelled socio-technical projects in French cities}

\subsection{Administration}

Of those innovations highlighted under the smart city label, a certain number relate directly to egovernment under headings such as informing inhabitants and enhancing access to individual files (1) (This numbering refers to Table 1 abbreviations). These are websites, "one-stop shop" telephone-based services developed by cities (e.g., Nantes dans ma poche - i.e., pocket-sized guide to Nantes) or turnkey service platforms provided by start-ups "my city in my pocket" (2), multi-service payment cards (Bordeaux) (3), information points or smart parking metres that can be used to pay for parking and obtain information (Chartres) (4).

The whole idea of smart public bodies (Meijer \& Bolivar, 2016) is largely absent from official discourse although cities have bought into the notion: recruitment of a data officer (Mulhouse, Lyon), standardisation (IT urbanisation) of in-house digital offering (Lille, Bordeaux), or a comprehensive customer relations management system (CRM linked to a one-stop shop (in Issy les Moulineaux). 


\subsection{Services}

"Smart city"-labelled services include both new services and revamped forms of old services. Firstly, the question of digital access is addressed, especially free wifi in various public places (Strasbourg, Mulhouse) as well as help with installing fibre-optic broadband (Dijon). There is also a major focus on mobility, providing enhanced information to commuters on public transport (5), finding available parking using sensors under each parking space as in Nice (6) or through the use of look-ahead algorithms as has been done in Issy les Moulineaux or Bordeaux (7). New services include car sharing (8) (large-scale electric vehicle programmes in Paris), bike sharing services in most cities (8), or more experimental initiatives involving driverless cars (Rouen) (9). Certain municipalities are expanding this dynamic to the sharing economy by overseeing car-pooling initiatives (Lille, Bordeaux) (10) or making it easier to rent private car parks by the hour in the case of Issy (11). Big data has also applications in transportations for various surveys (12).

Alongside the work of municipalities, a lot of effort has gone into keeping elderly people in their own homes (alerts given by phone or when toilets are not used (13)). New digital services have also been used to provide tourist information (phone application (14) or 3D imaging of the city (33)).

\subsection{Regulation of urban networks}

Many "smart city"-labelled features of new urban management technologies, aim for maximum efficiency in the production of services or in infrastructure management. In many cases, this is directly related to resource efficiency drives and a lot of "green city" or "eco-neighbourhood" projects - mainly concerning energy, water, sanitation, waste management and road traffic - have been rebranded as "smart city" projects by putting the focus on digital technology.

The most widespread practice (because it generates immediate savings) is variable lighting tripped by the presence of pedestrians (15). The subject of energy consumption in private buildings was central to early innovations (Lyon confluence) and thermostatic valves for public buildings have also been developed in Nantes and Rennes (16). Measuring how full municipal dumps are and how much individual bins weigh makes it possible to optimise waste collection route efficiency (17). This can also be applied to networks themselves by optimising the flow of waste in sewers as attempted in a multi-network experiment organised around the University of Lille (18). In the transport field, lights automatically go green when a bus arrives (19).

In addition to these automatic processes, "smart grids" (20) actively get the population involved in regulation in a more original manner. As part of a resource efficiency drive or civic-mindedness campaign, inhabitants are asked to modify their consumption patterns. Smart electric grids using "Linky" smart meters installed in households all over the country combine optimal network resource allocation with incentives to cut consumption at peak hours, thus illustrating this practice on a large scale. Households in a neighbourhood in Lyon and in Nantes were given tablet devices to help them track and optimise their electricity and water consumption. In Besançon the collection of unsorted waste is billed by weight (21). In Montpelier, videophones in each apartment can be used to warn of flooding (22).

The most significant applications of big data are in the automatic regulation of urban networks. Cities can then use deep learning to combine and interpret data and come up with a cross-cutting analysis of urban practices. Many of these multi-dimensional processing techniques are still in the experimental phase: Issy les Moulineaux has harnessed image recognition technology to other available data; Lyon tracks its own water consumption; Dijon has built a multi-sector urban network management centre supported by historical service operators; in Nice and Montpelier, IBM has provided a turnkey flood management 
system (23). Mobility in transport and public areas has been tackled in Rennes using transport mapping data (12), in Mulhouse by harnessing user Wifi footprints, and in Paris via image processing technology (24).

\subsection{Public policies}

A number of public policy areas are affected by smart city initiatives such as security policies, policies to support the economy and urban planning.

Public security and control are less consensual issues and cities may be reticent about giving controversial activities a "smart-city" label. So, for example, despite being technologically quite similar to the socio-technical processes described previously, cars fitted with Automatic License Plate Recognition technology (25) that can identify car owners who have not paid their parking charges are labelled "smart city" in certain cities (Chartres) but not in others (Paris). But some municipalities are happy to link urban security and smart cities: Marseille has clearly focused its security innovations around this theme with preventive initiatives based around the automatic interpretation of video camera data (25) and crime anticipation algorithms (26).

Economic development is mainly promoted through support for the digital sector and traditional business cluster-type initiatives. Certain economically distressed cities and districts (Roubaix, Plaine commune, Besançon) have set up training programmes to promote digital literacy among young people and help trades people to communicate using smartphone apps or terminals (27). Open data nurture start-ups providing urban services (28). These may include support with house buying, trip planning or managing energy retrofits in buildings. Nevertheless, the growth in these types of services has not fully lived up to the expectations of those who promoted the related law (Denis \& Goëta, 2017) and numerous cities have organised competitions to encourage the use of these data, hackathons (29), "geek-focused" fab labs, partnerships between start-ups and major bodies like the City of Lyon with the TUBA initiative or Grenoble, or large trade fairs to promote start-ups (Nice, Marseille, Bordeaux, Paris). One recent trend involves setting up a platform that gives access to real-time data.

Urban planning practices are mainly transformed by the evolution of geographical information with automatic image recognition (30) on the one hand and crowd sourcing practices on the other (like open street map (31)). This is part of a longer-term strategy of pooling information around geographical information systems (GIS) deployed in places like Rennes or Plaine-Commune in the suburb of Paris. Making information accessible in shareable form also helps data circulate between different municipal services.

\subsection{Democracy}

Several municipalities (particularly Mulhouse, Rennes, Nantes and Paris) have linked the idea of the smart city to participative democracy and the possibility of expressing an opinion about projects (32). The key development, vis-à-vis traditional e-government practices, is to shift web-based surveys onto smartphones in order to reach a younger population. Significant participative budgets, such as that provided by the City of Paris, have benefited from enhanced voting access for the general population.

More specifically, the use of 3D imaging (33) helps inhabitants visualise future projects and enhances the public debate. Rennes provides a virtual representation of the entire city while Besançon provides a representation of a redeveloped district. In Strasbourg, debates are organised around on-line participatory maps (34). Some cities have deemed that civic-mindedness is contingent on having a command of these new digital practices and they offer practical training around the large public fab lab in Rennes in 


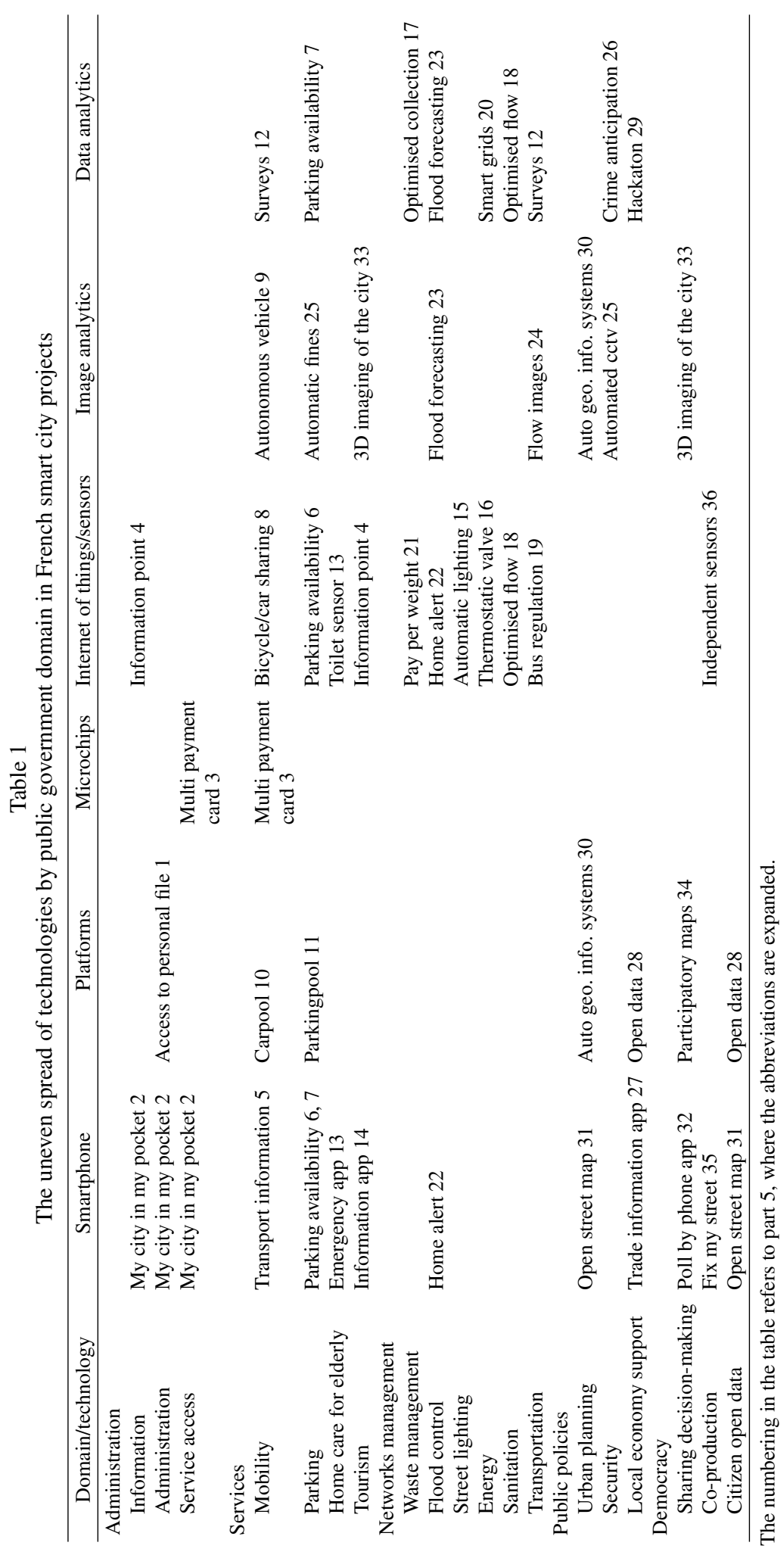


several community centres. Applications for flagging up problems with public amenities (holes in the street, damaged street furniture, etc.) using GPS/geo-tracking and sending a photo, together with better access have also shaken up traditional practices based on letters of complaint ("fix my street", 35). Coproduction also includes wikis for neighbourhoods and cities.

Open data is supposed to facilitate a greater transparency from a democratic perspective. But in concrete terms, open data means providing spreadsheets containing disaggregated data and processing this into meaningful form. Consequently, examples of disaggregated data use by the general public are relatively rare. Self production by independent associations of data on transport (open street maps) or noise (noise tube) using smartphone interfaces (36) are both easier to access because they are formatted by a platform, and less likely to be sorted in a selective manner by public bodies. Cities such as Rennes have supported associations that wish to develop these alternative data capture techniques. Several cities have developed noise and pollution data capture using service vehicles to meet a specific public need (Paris, Grenoble) and public conferences/seminars have been organised in Grenoble and Lille to promote awareness of the use of such data.

This presentation of smart city projects according to the different urban domains highlights firstly that the technologies most often used in the projects are mainly based on smartphones and GPS, data exchange platforms, chips, the Internet of things, automated image processing and sophisticated data analytics methods. However, these technologies are not used in a uniform manner across the different urban domains. The following table highlights these differences.

\section{Smart cities: Emerging trends}

All of the various label providers (i.e., financing bodies, media, municipalities) refer to relatively similar practices and these have a number of recurring trends.

\subsection{Omnipresent technological dimension}

The first feature of the French situation is the omnipresence of technology. Metaphorical uses of the notion of intelligence (Giffinger \& Gudrun, 2010; Meijer \& Bolivar, 2016) are fairly present in general political discourse which focuses on the importance of people vis-à-vis technology but the concrete examples referred to almost always embrace digital technology. The rare exceptions concern sustainable development-type projects backed by the state financing bank CDC to complete older "green city" project, or a few non-technical economic development initiatives that nonetheless focus on digital technology or operating arrangements associated with the digital transformation such as "one-stop shops". So, behind the banner of the smart city and all the attendant rhetoric there is a practical imperative: the impact of new digital technology on the management of city life.

Rather than an integrated model (Layne \& Lee, 2001; Norris \& Reddick, 2013), the dominant development paradigm is an accumulation of sector-based innovations equivalent to smartphone apps (Ménard, 2017). Both the level and approaches to development are different. Some are in the experimental phase, some restricted to a neighbourhood or a few buildings, some disseminated in a general way throughout several cities, some operated under a municipal concession arrangement, while others are part of miscellaneous partnership-type arrangements with both large and small private businesses. But no single city has an overall integrated programme for these innovations and this was borne out by a large parliamentary enquiry into this whole area (Belot, 2017). 


\subsection{The uneven spread of technologies by public government domain}

Technologies are clearly differentiated along different domains: cutting-edge innovations are to be found in the regulation of urban networks rather than in e-government. Websites, which lie at the heart of e-governance, are still very much present however, the widespread use of the smartphone is gradually transforming this web-based interface. First, round-the-clock access is transforming uses (bus timetables won't be used in the same way in the house as in the city). Second, GPS is generating new opportunities (e.g., immediately being able to localise a problem on a road/street). However, the objects of the smart city are broader than those of e-government which mainly comprise administrative data (information about people, the application of rules, how services work, etc.). The examples presented combine material that belongs more in the realm of engineers than administrators with data that concerns not citizens but objects (building temperature, rain levels, the position of cars within a city, waste tonnage, etc.). The most sophisticated technologies linked to artificial intelligence are associated mainly with automatic network regulation.

Table 1 presenting the experiments by combining domains and technologies highlights unequally shared configurations between the two dimensions. Administrative dimensions are mainly affected by the opportunities provided by the transition from website to smartphone and by RFID tags, particularly for multiservice cards. Network regulation functions - self-regulatory and user-centric regulation - are affected by technologies associated with the Internet of things and data analytics.

\subsection{From e-democracy to responsible co-production}

The possibility of citizens using new technologies to interact directly is one key argument in favour of smart cities as it was for e-governance. However, if we limit the whole democracy debate to ability to participate in decision-making, we encounter very few innovations among the "smart city"-labelled practices identified. This does not mean that the political dimension is absent: this is bound up less with how an opinion is expressed in decision-making than with the expression of civic responsibility within a co-production framework. The afore-mentioned technologies provide many more individualised possibilities for the responsible citizen wishing to co-produce public initiatives (Linders, 2012). Everyone is being called upon to change their behaviour in favour of sustainable development (on economic or civic grounds): lowering the thermal comfort in their homes, shifting electricity use to off-peak periods, sorting waste, etc. Citizens may produce data passively (by allowing their GPS footprint to be accessed) or actively by providing information and they may become involved in processing these data in certain situations (e.g., wiki, open street map). They may also participate in the upkeep of public spaces in a renewed form by flagging up problems or be called on to provide services by making their parking space available for the public for example.

\subsection{New and old private stakeholders}

Although the whole issue of relations with service provider companies is not related to the purpose of "smart city"-labelling, certain characteristics of private stakeholders involved in "smart city"-labelled projects and the forms of relationships established form part of the information gleaned from this survey of smart projects.

In the bulk of cases, "smart city"-labelled innovations associate local government with an SME innovation start-up, sometimes with links to the local university. These start-ups may leverage open data, 
sometimes supported by hackathon-type initiatives. Some have developed products that are distributed in a number of cities.

Major digital corporations that had not previously worked with municipalities are associated with certain projects. IBM has been closely involved in smart city projects in Nice and Montpellier where these companies operate a management centre and a flood prediction facility, respectively. In Rouen where it has a number of plants, the automaker Renault has begun experimenting with driverless vehicles. Toshiba has signed a partnership with the City of Lyon to optimise energy consumption in a new neighbourhood (Confluence). Cisco has developed a more localised traffic management service offering, initially in Issy les Moulineaux, then in Nice and Paris on a boulevard and in a square, respectively.

While the novelty of these start-up and digital majors has caught the eye, other more traditional actors such as large construction and urban services corporations have also featured in certain projects. Concession operators in the transport and sanitation sectors are associated with numerous innovations in optimising infrastructure regulation. The most striking example is in Dijon where an infrastructure fibre-optic offering is linked to the creation of a central control facility and backed by a consortium of long-standing municipal partners (Bouygues, EDF, and Suez).

\section{Discussion}

The fact that the smart city is built primarily as a series of technological solutions and not as an overriding social project (Giffinger \& Gudrun, 2010) reflects the depoliticised approach to French municipal management. This does not signify that the choice of innovations is not underpinned by ideological choices: the basket of innovations is not the same for all cities (more of a social focus in cities like Lille and Besançon, more focused on security in Marseille and Nice, and more focused on citizen participation in Rennes and Paris). However in all cases, technology is presented as simply optimising existing applications. Moreover, the developments associated with artificial intelligence reinforce the mechanisms for automatic regulation of urban networks (flood management, traffic management, and energy use). The development of digital applications then becomes part of the "invisible pilots" (Lorrain, 2004) that structure (outside of the debate) the day-to-day management of the city.

The mismatch in technological opportunities between administrative and engineering domains helps reinforce the development inequality that could already be detected in the early 1990s (Dupuy, 1992). The smart city reinforces the two-speed modernisation of French cities. On the one hand, the administrative opportunities offered by the smartphone simply add to this list of functionalities in an e-government process that is taking rather a long time to roll out as it is in other countries as well (Norris \& Reddick, 2013). On the other hand, the technologies linked to artificial intelligence accelerate the momentum (Hughes, 1993) of hi-tech solutions in the management of urban networks. In this last sector (infrastructure), the fact that innovations often take the form of standalone applications hosted by start-ups means that these new technologies are not enough to transform the very foundations of an infrastructure network and their place in the city (Dupuy \& Tarr, 1988), as for example tramways were able to do in French cities in the 2000s. Smart city support networks (cable, fibre-optics) pre-date "smart city"labelled projects even though the new innovations legitimise the process of extending these networks. Innovations in sewage or energy performance in buildings help optimise the energy consumed by existing networks without really inventing new infrastructures or a post-network city (Coutard \& Rutherford, 2015). The key new infrastructures are those associated with new forms of mobility: bike and car sharing services organised around a battery recharge infrastructure (Huré, 2017) and, on a more experimental level, a field support network for driverless cars. While technological factors lie at the heart of the first 
wave of technophile research into smart cities (Batty, 2013; Schaffers et al., 2011), and although it has been formalised in organisational approaches (Nam \& Pardo, 2011), the technological development of smart city projects has not yet been differentiated by domain and merits greater attention.

Certain co-production opportunities associated with new digital technologies afford renewed importance to proximity and dealing with grievances in the socio-technical regime of cities. Although they are genuinely new, the opportunities for interaction provided by new technologies are a continuation of a practice rooted in proximity and dealing with grievances specific to the socio-technical regime of French cities. The success of "fix my street" type initiatives where citizens can flag up and geolocate a problem in the public space (De Feraudi \& Saujot, 2017), renew and reinforce earlier practices that have moved from letters of complaint/grievances and telephone switchboards that collated requests, onto the net. Capacity to participate in self-regulation of networks rather enhances the automatic regulation dynamics of the afore-mentioned networks. As regards participation in decision-making, the opportunities offered by smartphones or certain 3D representations simply round out a whole range of tools for cities that already encouraged inhabitant participation.

The most significant break with the socio-technical regime triggered by the new digital processes is potentially related to long-term relationships with major urban service provider businesses. The specific French model of urban capitalism (Lorrain, 2005b; Baraud Serfati, 2011; Huré, 2017) is being shaken up by the arrival of new types of stakeholders. Indeed, two new types of private actors have appeared along with these new digital initiatives: major corporations specialised in digital services and much smaller start-up-type structures. These new arrivals offer the possibility of affecting a considerable shift in the socio-technical model with the end of long-term commitments to a limited number of businesses. Nevertheless, it is too early to assess the long-term stability of these new arrangements. There are a few pointers that reflect how difficult it is for big corporations to stabilise their positions in cities (withdrawal of Cisco and curtailing of IBM's role in Nice, withdrawal of IBM in Montpellier) which corresponds to IBM's bigger problems in the wider world (Alizadeh, 2017). Indeed, in several cases, independent start-ups have linked up with, or been bought over by historical urban service operators. The case of Dijon where an integrated city management offering is being proposed by a consortium of established businesses from the sector (public works, services) in association with start-ups is part of a configuration reflecting continuity in the socio-technical regime of French cities. It is still too early to assess the balance between different types of private enterprise involved in urban management but it already appears that corporate smart cities (Hollands, 2015) in this variegated context (Rossi, 2016) always reserve a key role for existing service companies.

The elements of continuity that emerge originate in a number of dimensions comprising the sociotechnical regime, as summarised by Senger et al. (2016): "networks of actors and social groups, formal, normative and cognitive rules, material and technical elements". The fact that technical elements are a factor of consensus stems from the regulatory framework of French local democracy which leads to coalition government as well as to the materiality of an offering in very varied domains. Unequal deployment of technologies between the administration and engineering domains is due to both the material features of different administrative domains or energy or water flows. It is due to specific rules for protecting personal data associated with administrative files that do not apply to data captured by technical sensors. It is also due to the R\&D capacity of big private corporations in charge of engineering functions, characteristic of the French urban capitalism model and to the symmetrical absence of technical networking of cities such as that observed with the German Stadwerke (Barraqué, 1992). The fact that the people running French cities give serious consideration to the co-production of opportunities made possible by sensors or smartphones stems from the election of mayors by universal suffrage, but this 
attitude has also been progressively incorporated into the design of an organisation and the cognitive rules for technical services focused on the resolution of small day-to-day problems. This is also rooted in cognitive rules and the expectations of the population which elects its mayor based on their perception of day-to-day management as much as ideological criteria. Lastly, the search for technological solutions with private concession operators is enshrined in the specific regulatory framework for the concession in which the city remains the owner of the infrastructures. For over a century this has facilitated the deployment of these operators in very stable public/private networks that lead to the renewal of concessions for very long periods, unlike in other countries such as the United Kingdom (Lorrain, 2005b). We may observe differences between cities concerning the role reserved for local democracy for example, or autonomy vis-à-vis concession operators, however there are very strong federating elements at national level. These patterns originate from the regulatory framework that structures management and local democracy at national level and this socio-technical urban regime must be assessed at this level which has been neglected by numerous studies that covered only a single operation or city.

\section{Conclusion}

The confrontation of a systematic overview of "smart city"-labelled projects in 20 French cities and a summary presentation of the main features of the urban socio-technical regime of French cities primarily highlight lines of continuity. A number of trends are directly apparent in - or lead to the renewal of - the continuity of the components of the socio-technical regime of French cities. Technologies are not evenly developed along different domains: the fact that the most sophisticated innovations are deployed in the regulation of networks rather than in e-government reinforces two-speed urban modernisation (Dupuy, 1992). The mainly technological character of these projects is part of the continuity of a depoliticised strategy for managing technical matters. Other trends also appear to drive the reinvention of the urban socio-technical regime. Co-production opportunities renew a tradition of local governance and processing of grievances. Cooperation between start-ups and public service concession holders are likely to renew the French model of urban capitalism.

Our argument of continuity in the urban socio-technical regime challenges a strong presumption of two important components of smart city research. The techno-optimistic trend driven by academics who have a background in information technology (Batty, 2013) has focused on the potentialities of new technologies. The geographers who subsequent criticized the approach took the novelty aspect for granted.

The analysis makes it possible to specify the form of this continuity. It cannot be reduced to just highlighting administrative blockages or resistance, as has been done in the case of e-government, with a disparity between promises of a comprehensive transformation of administration through e-government (Layne \& Lee, 2001) and actual reality (Norris \& Reddick, 2013; Torres et al., 2005). At this level of analysis, we don't observe technological lock-in (David, 1985): the range of technology appears extremely open, at least in the experimental phase. However, this point needs to be validated by more detailed research focusing on specific technologies. It is possible to detect a number of direct ties to existing innovation networks (Meijer \& Thaens, 2018) linked to universities (e.g., Lille), a corporation's location at a given site (IBM in Nice and Montpellier, Renault for driverless vehicles in Rouen), or changes in the way innovation is financed (e.g., the shift from financing "green cities" to "smart cities" by the EU or Caisse des dépôts). However, it is in the broader context of the urban socio-technical regime that labelled projects appear to be guided by existing municipal administration practices. It is 
from a system perspective that this continuity must be assessed (Geels, 2004; Rip \& Kemp, 1998; Raven et al., 2019).

Smart city projects seem to be more popular when they strengthen longstanding features of the sociotechnical regime. This does not mean that there are no new developments, particularly in relations with companies and citizens, however such new developments do not interfere with the socio-technical regime as enshrined in the niche theory (Carvahlo, 2014). It is this double movement of transformation and reinforcement - what could be termed a reinvention - that emerges from the list of projects undertaken in twenty French cities.

This article has two limitations. First, France's urban socio-technical regime may be exceptionally stable when compared to that of other countries. Secondly, the survey approach used here, using publicly accessible information, is an exploratory one.

The approach could be extended by creating a systematic record of practices using a questionnairebased survey similar to that developed to measure the adoption of management tools in local government departments (Kuhlmann et al., 2008; Poister \& Streib, 1994) and by applying this method in a number of countries with differentiated socio-technical regimes and comparable smart city definitions (in different European countries, for example).

\section{Acknowledgments}

This research has been financed by the "Institut CDC pour la recherche" of the French public bank Caisse des dépôts et consignations. I thank Stève Bernardin, David Géranger, Ismail Hamoumi, Victor Maghin and Alexandre Mathieu Fritz who were part of this research project and the anonymous reviewers.

\section{References}

Aibar, E., \& Bijker, W.E. (1997). Constructing a city: The Cerdà plan for the extension of Barcelona. Science, Technology, \& Human Values, 22(1), 3-30.

Alizadeh, T. (2017). An investigation of IBM's Smarter Cites Challenge: What do participating cities want? Cities, 63, 70-80. Angelidou, M. (2014). Smart city policies: A spatial approach. Cities, 41, 3-11.

Anthopoulos, L. (2017). Smart utopia VS smart reality: Learning by experience from 10 smart city cases. Cities, 63, 128-148.

Baccarne, B., Mechant, P., Schuurman, D., Colpaert, P., \& De Marez, L. (2014). Urban socio-technical innovations with and by citizens. Interdisciplinary Studies Journal, 3, 143-156.

Baraud-Serfaty, I. (2011). La nouvelle privatisation des villes. Esprit, 3, 149-167.

Barraqué, B. (1992). Water management in Europe: beyond the privatization debate. Flux, 8, 7-26.

Barthélemy, J.R. (1989). Le changement de culture technique des services municipaux: le cas d'une ville moyenne, Castres. Les Annales de la Recherche Urbaine, 1(44), 101-108.

Batty, M. (2013). Big data, smart cities and city planning. Dialogues in Human Geography, 3(3), 274-279.

Belot, L. (2017). De la smart city au territoire d'intelligence(s), rapport au premier ministre sur l'avenir des smart cities. Paris, France: Matignon.

Bezançon, X. (1997). Les services publics en France de la révolution à la première guerre mondiale. Paris, France: Presses de l'école des ponts.

Biland, É. (2010). Les ambiguïtés de la sélection par concours dans la fonction publique territoriale: une institutionnalisation inachevée. Sociologie du Travail, 52(2), 172-194.

Borraz, O. (1995). Politique, société et administration les adjoints au maire à Besançon. Sociologie du travail, 221-248.

Bulkeley, H., McGuirk, P.M., \& Dowling, R. (2016). Making a smart city for the smart grid? The urban material politics of actualising smart electricity networks. Environment and Planning A: Economy and Space, 48(9), 1709-1726.

Carvalho, L. (2014). Smart cities from scratch? A socio-technical perspective. Cambridge Journal of Regions, Economy and Society, 8(1), 43-60. 
Courmont, A. (2015). Open data et recomposition du gouvernement urbain: de la donnée comme instrument à la donnée comme enjeu politique. Informations Sociales, 5, 40-50.

Coutard, O. (Ed.). (2002). The governance of large technical systems. Abingdon-on-Thames, UK: Routledge.

Coutard, O., \& Rutherford, J. (Eds.). (2015). Beyond the Networked City: Infrastructure reconfigurations and urban change in the North and South. Abingdon-on-Thames, UK: Routledge.

Cowan, R. (1990). Nuclear power reactors: a study in technological lock-in. The Journal of Economic History, 50(3), 541-567.

Cowley, R., Joss, S., \& Dayot, Y. (2018). The smart city and its publics: insights from across six UK cities. Urban Research \& Practice, 11(1), 53-77.

David, P.A. (1985). Clio and the Economics of QWERTY. The American Economic Review, 75(2), 332-337.

De Feraudy, T., \& Saujot, M. (2017). Une ville plus contributive et durable: crowdsourcing urbain et participation citoyenne numérique. Iddri Study, 4, 1-72.

Denis, J., \& Goëta, S. (2017). Les facettes de l'Open Data: émergence, fondements et travail en coulisses. In Menger, P.M., \& Paye, S. (Eds.). Big data et traçabilité numérique. Les sciences sociales face à la quantification massive des individus, Paris, France: Collège de France, pp. 121-138.

Desage, F., \& Guéranger, D. (2011). La politique confisquée: sociologie des réformes et des institutions intercommunales. Vulaines sur Seine, France: Croquant.

Dupuy, G. (1978). Urbanisme et technique: chronique d'un mariage de raison. Paris, France: Centre de recherche d'urbanisme.

Dupuy, G. (1992). L'informatisation des villes, Paris, France: Presses universitaires de France.

Dupuy, G., \& Tarr, J.A. (Eds.). (1988). Technology and the Rise of the Networked City in Europe and America. Philadelphia: Temple University Press.

Edwards, P.N., Bowker, G.C., Jackson, S.J., \& Williams, R. (2009). Introduction: an agenda for infrastructure studies. Journal of the Association for Information Systems, 10, 364-374.

Evans, J., Karvonen, A., \& Raven, R. (Eds.). (2016). The experimental city. Abingdon-on-Thames, UK: Routledge.

Faivre d'Arcier, B., Lecler, Y., Granier, B., \& Leprêtre, N. (2016). Lyon smart community. Projet SMARTMOB. Rapport final. HAL. https://halshs.archives-ouvertes.fr/halshs-01382756.

Farias, I., \& Widmer, S. (2018). Ordinary smart cities. How calculated users, professional citizens, technology companies and city administrations engage in a more-than-digital politics. Technoscienzia, Italian Journal of Science \& Technology Studies, $8(2), 43-60$.

Geels, F.W. (2004). From sectoral systems of innovation to socio-technical systems: Insights about dynamics and change from sociology and institutional theory. Research Policy, 33(6-7), 897-920.

Giffinger, R., \& Gudrun, H. (2010). Smart cities ranking: an effective instrument for the positioning of the cities? Architecture, City and Environment, 4(12), 7-26.

Graham, S., \& Marvin, S. (2002). Telecommunications and the city: electronic spaces, urban places. Abingdon-on-Thames, UK: Routledge.

Greenfield, A. (2013). Against the smart city. New York city, NY: Do projects.

Henriot, C., Douay, N., Granier, B., Languillon-Aussel, R., \& Leprêtre, N. (2018). Perspectives asiatiques sur les smart cities. Flux, (4), 1-8.

Hollands, R.G. (2008). Will the real smart city please stand up? Intelligent, progressive or entrepreneurial? City, 12(3), 303-320.

Hollands, R.G. (2015). Critical interventions into the corporate smart city. Cambridge Journal of Regions, Economy and Society, 8(1), 61-77.

Hommels, A. (2005). Studying obduracy in the city: Toward a productive fusion between technology studies and urban studies. Science, Technology, \& Human Values, 30(3), 323-351.

Hughes, T.H. (1993). Networks of power: electrification in Western society, 1880-1930. Baltimore Ma: John Hopkins University Press.

Huré, M. (2017). Les mobilités partagées. Nouveau capitalisme urbain. Paris, France: Les publications de la Sorbonne.

Jeannot, G. (1995). Faire avec les usagers. Les ingénieurs territoriaux entre production et démocratie. In Joseph, I., \& Jeannot, G., Métiers du public. Les compétences de l'agent et l'espace de l'usager, Paris France: CNRS Éditions, pp. 319-331.

Jeannot, G., \& Guillemot, D. (2010). Réformer par les outils ou par les hommes? Un bilan quantitatif de la "modernisation de la gestion" de l'Etat. Politiques et Management Public, 27(4), 73-102.

Jeannot, G., Van de Walle, S., \& Hammerschmid, G. (2018). Homogeneous national management policies or autonomous choices by administrative units? Inter-and intra-country management tools use variations in European central government administrations. Public Performance \& Management Review, 41(3), 497-518.

Jin, J., Gubbi, J., Marusic, S., \& Palaniswami, M. (2014). An information framework for creating a smart city through internet of things. IEEE Internet of Things Journal, 1(2), 112-121.

Karvonen, A., Cugurullo, F., \& Caprotti, F. (Eds.). (2018). Inside Smart Cities: place, politics and urban innovation. Abingdonon-Thames, UK: Routledge.

Kitchin, R. (2014). The data revolution: Big data, open data, data infrastructures and their consequences. New York NY: Sage. 
Köhler, J., Geels, F., Kern, F., Onsongo, E., \& Wieczorek, A. (2017). A research agenda for the Sustainability Transitions Research Network (STRN). Sustainable Consumption Institute Manchester, UK: University of Manchester.

Konvitz, J.W., Rose, M.H., \& Tarr, J.A. (1990). Technology and the city. OAH Magazine of History, 5(2), 32-37.

Kuhlmann, S., Bogumil, J., \& Grohs, S. (2008). Evaluating administrative modernization in German local governments: success or failure of the "new steering model"? Public Administration Review, 68(5), 851-863.

Latour, B., \& Hermant, E. (2006). Paris: invisible city. Paris France: La Découverte.

Layne, K., \& Lee, J. (2001). Developing fully functional E-government: A four stage model. Government Information Quarterly, 18(2), 122-136.

Linders, D. (2012). From e-government to we-government: Defining a typology for citizen coproduction in the age of social media. Government Information Quarterly, 29(4), 446-454.

Lorrain, D. (1991). De l'administration républicaine au gouvernement urbain. Sociologie du Travail, 33, 461-484.

Lorrain, D. (2004). Les pilotes invisibles de l'action publique. Le désarroi du politique? In Lascoumes, P., Le Galès, P. Gouverner par les instruments, Paris France: Presses de sciences po, pp. 163-197.

Lorrain, D. (2005). La firme locale - globale: Lyonnaise des Eaux (1980-2004). Sociologie du Travail, 47(3), 340-361.

Lorrain, D. (2005b). Urban capitalisms: European models in competition. International Journal of Urban and Regional Research, 29(2), 231-267.

Lorrain, D., Halpern, C., \& Chevauché, C. (2018). Villes sobres: Nouveaux modèles de gestion des ressources. Paris, France: Presses de sciences po.

Luque-Ayala, A., \& Marvin, S. (2015). Developing a critical understanding of smart urbanism? Urban Studies, 52(12), 21052116.

Markard, J., Raven, R., \& Truffer, B. (2012). Sustainability transitions: An emerging field of research and its prospects. Research Policy, 41(6), 955-967.

McLean, A., Bulkeley, H., \& Crang, M. (2016). Negotiating the urban smart grid: Socio-technical experimentation in the city of Austin. Urban Studies, 53(15), 3246-3263.

Meijer, A., \& Bolivar, M. (2013, September). Governing the smart city: Scaling-up the search for socio-techno synergy. In 2013 EGPA Conference Proceedings.

Meijer, A., \& Bolívar, M.P.R. (2016). Governing the smart city: a review of the literature on smart urban governance. International Review of Administrative Sciences, 82(2), 392-408.

Meijer, A., \& Thaens, M. (2018). Urban technological innovation: Developing and testing a sociotechnical framework for studying smart city projects. Urban Affairs Review, 54(2), 363-387.

Meijer, A., Thaens, M. (2018b). Path dependency of smart cities. Historical institutionalism as a lens for understandinc smart cities, Paper presented at EGPA, 2018, Lausanne.

Ménard, F. (2017). Penser la ville intelligente. Urbanisme, 407, 32-36.

Meeus, M.T., \& Edquist, C. (2006). Introduction. In Hage, J., Meeus, M., Meeus, M.T., \& Edquist, C. (Eds.). Innovation, science, and institutional change: a research handbook, Oxford UK/Oxford University Press, pp. 24-37.

Nam, T., \& Pardo, T.A. (2011). Conceptualizing smart city with dimensions of technology, people, and institutions. In Proceedings of the 12th Annual International Digital Government Research Conference: Digital Government Innovation in Challenging Times, pp. 282-291.

Neirotti, P., De Marco, A., Cagliano, A.C., Mangano, G., \& Scorrano, F. (2014). Current trends in smart city initiatives: Some stylised facts. Cities, 38, 25-36.

Nez, H. (2011). Nature et légitimités des savoirs citoyens dans l'urbanisme participatif. Une enquête ethnographique à Paris. Sociologie, 2(4), 387-404.

Norris, D.F., \& Reddick, C.G. (2013). Local e-government in the United States: Transformation or incremental change? Public Administration Review, 73(1), 165-175.

Poister, T.H., \& Streib, G. (1994). Municipal management tools from 1976 to 1993: An overview and update. Public Productivity \& Management Review, 115-125.

Raven, R., Sengers, F., Spaeth, P., Xie, L., Cheshmehzangi, A., \& de Jong, M. (2019). Urban experimentation and institutional arrangements. European Planning Studies, 27(2), 258-281.

Rip, A., \& Kemp, R. (1998). Technological change. Human Choice and Climate Change, 2(2), 327-399.

Rossi, U. (2016). The variegated economics and the potential politics of the smart city. Territory, Politics, Governance, 4(3), 337-353.

Schaffers, H., Komninos, N., Pallot, M., Trousse, B., Nilsson, M., \& Oliveira, A. (2011). Smart cities and the future internet: Towards cooperation frameworks for open innovation. In Domingue, J. The future internet, Berlin Germany: Springer, pp. 431-446.

Sengers, F., Wieczorek, A.J., \& Raven, R. (2019). Experimenting for sustainability transitions: A systematic literature review. Technological Forecasting and Social Change, 145, 153-164.

Shelton, T., Zook, M., \& Wiig, A. (2015). The 'actually existing smart city'. Cambridge Journal of Regions, Economy and Society, 8(1), 13-25. 
Torres, L., Pina, V., \& Acerete, B. (2005). E-government developments on delivering public services among EU cities. Government Information Quarterly, 22(2), 217-238.

Turletti, N. (2014). Measuring smart cities transition: an analytical model (Doctoral dissertation, Politecnico di Torino).

van Winden, W., \& van den Buuse, D. (2017). Smart city pilot projects: Exploring the dimensions and conditions of scaling up. Journal of Urban Technology, 24(4), 51-72.

Veltz, M., Rutherford, J., \& Picon, A. (2018). Smart urbanism and the visibility and reconfiguration of infrastructure and public action in the French cities of Issy-les-Moulineaux and Nice. In Karvonen, A., Cugurullo, F., \& Caprotti, F. (Eds.). (2018). Inside Smart Cities: place, politics and urban innovation, Abingdon-on-Thames, UK: Routledge, pp. 133-148.

Zaza, O. (2016). L'E-gouvernance pour la participation citoyenne: imaginaires du futur, nouvelles compétences et impacts territoriaux. Pyramides. Revue du Centre d'études et de Recherches en Administration Publique, 26/27, 163-190. 